\title{
Research-Based Pocket Book as Fungi Learning Media
}

\author{
Lilis Supratman ${ }^{a *}$, Yamin $^{\mathrm{a}}$ \\ ${ }^{a}$ Faculty of Teacher Training and Education, Universitas Pakuan, Bogor, Indonesia \\ oktianfajarnugroho@gmail.com*; anna.permanasari@upi,edu; harry.firman@upi.edu; rian@upi.edu \\ *Corresponding author
}

\begin{tabular}{|c|c|}
\hline Article Info & ABSTRACT \\
\hline Article history: & Fungi endophytic is microscopic so that the results of the \\
\hline Received Oct 1, 2021 & documentation of the research can be documented in the form of a \\
\hline Revised Oct 28, 2021 & The book pocket is a media of learning that are practical and \\
\hline Accepted Oct 29, 2021 & endophytic obtained on the organs of Ciplukan plants namely roots, \\
\hline Keywords: & having a substance compound antimicrobials against pathogenic \\
\hline Endophytic & bacteria. Test the feasibility of a pocket book to be used as a source of \\
\hline Book pocket & experts. Validation results show an average of $84.31 \%$ resulting in \\
\hline Fungi & $\begin{array}{l}\text { 'valid' criteria. The validator's statement based on validation states } \\
\text { 'pocketbooks can be used as a source of learning'. }\end{array}$ \\
\hline
\end{tabular}

This is an open access article under the CC BY-SA license.

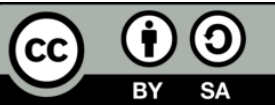

\section{Introduction}

Fungi is one of subject matter in secondary schools. Fungi are macroscopic and microscopic. The macroscopic fungi are very easily to observed with the naked eye. The microscopic fungi are very hard to imagine. One example of fungi microscopic is fungi endophytic that live inside plant tissues without causing symptoms of the disease on the host plant. Documentation of the results of research characterization of fungi endophyte in ciplukan plants (Physalis angulata L.) so that it is easy to understand it will be loaded in the form of a pocketbook. Dish of the pocket book includes a variety of fungi endophytic on Ciplukan plants that has the benefit that produce antibiotic substances and antimicrobial so the plant is not easy to be infected with pathogens.

Pocket book is small size book that can be stored in a pocket and easy to carry anywhere (Language Center, 2016). According to Sankarto and Endang (2008), pocket book has some characteristics, namely: (1) the number of pages is not restricted, a minimum of 24 pages, (2) are arranged to follow the rules of scientific writing popular, (3) the presentation of information in accordance with the interests, (4) the library that is referenced is not listed in the text, but are listed at the end of posts.

The pandemic is a challenge for teachers to improve the learning motivation of students. This challenge can be pursued in a variety of efforts. One of the efforts that can be modified, namely the enrichment of the learning media that interest in learning can grow until it can improve learning outcomes. The book is a complete learning resource because it contains a 
lot of materials, therefore it has been chosen by the teachers and students. But because it contains a lot of material then the number of pages will be very much and the book has a large size. This becomes the main reason, the book is considered to be less practical and have a load of light. Based on the above description, then one of the efforts that can be done is to make a pocket book.

The pocket book is one of the print media has its own advantages and disadvantages (Susilana et al., 2008 and Anjelita et al., 2018). The excess pocket book, namely: (1) can present the message or the information in the amount of that lot, (2) a message or information can be learned by the student in accordance with the needs and interest of speed respectively, (3) can be studied anytime and anywhere because it is easy to carry, (4) will be more interesting if equipped with pictures and colors, (5) repair or revision easy to do. The weakness of the pocket book, namely: (1) the manufacturing process takes considerable time, (2) printing material thickness will be boring and improve the interest of students who read it, (3) if the binding and the paper are bad, printed material will be easily damaged and torn. According to Mawardi (2009) a page on the pocket book ranges from 75 to 100 pages, so it can present the information in large quantities. The media paperback book selected because book pocket can load the information to be conveyed in large quantities, it contains elements of text, images, photographs and color, if it well presented can attract the interest and attention of students. In general, the schools only use the textbook which is dominated with so many texts and less picture.

The purpose of the pocket-book which is to facilitate the teacher gives the material fungi with the media visualization and the students easier to understand the characteristics of microscopic fungi A pocket book that has been made has been through the validation of expert learning media and expert grammar. Based on the description above, the pocket book needs to be held to facilitate the understanding of materials about fungi, especially those that are microscopic in size.

\section{Method}

This research is a combination of qualitative research and descriptive. According to Sugiyono (2011) stated qualitative research is a type of research conducted to examine the condition of natural objects in which the researcher acts as a key. While descriptive research is a procedure of solving the problem is investigated by tell and interpret data relating to facts, circumstances, variables, and the phenomena that occur during the study and serves as. The research method used is descriptive analytic. Samples for the research trial were conducted on learners at MTS Yasiba with a total of 32 students with a standard of minimum completeness score of 76. The research sample was conducted on learners at MTS Yasiba with a total of 30 students with a standard of minimum completeness score of 76 . The instrument used is a questionnaire to measure the feasibility of pocket books for learners to use. While the instrument to measure student learning outcomes reached the standard of minimum completeness using multiple choice tests as many as 40 questions.

The procedure for using a data pocketbook is explained through the following steps, namely: pocketbook design, observation of students' standard of minimum completeness values before using a pocket book, conducting the learning process using a pocket book, conducting a test of learning results after using a pocket book, teacher subjects filling out a questionnaire on eligibility for the use of pocket books as a learning medium, conclusions about the feasibility of using pocket books. 


\section{Results and Discussion}

Fungi are a close material to the foods that are usually present on every vegetarian menu. Students who are happy with fungi, he will be more interested in learning them and understanding the concept. In understanding the concept, innovative media is needed for learning to be meaningful (Sukaesih and Alimah, 2012). This is in accordance with the opinion of Murniasih and Ferdiani (2018) which states that the use of media can improve the understanding of laerners' concepts related to certain materials. Similar opinions that the use of media in learning can increase the interest of learners (Ferdiani, Murniasih and Suwanti, 2017). The use of pocket books can attract the interests of learners and facilitate in understanding certain materials (Ashari and Silvia, 2016).

The contents of the pocket book contain a variety of characterization fungi endophytic on Ciplukan plants. Organs of plants observed are the stems, roots and leaves. Each organ of the plant has a variety of fungi endophytic unique. Based on the results of the research, some of the isolates that were successfully characterized there were six isolates, some of which were the same isolate. The description of fungi endophytic in leaves consists of three isolates, on the stem consists of two isolates, on the root consists of a single isolate. Determination key fungi using the Description of the characterization of each isolate are described in table 1. While the anatomical structure of the fungi endophytic can be seen in figure 1 .

Table 1. Characterization of The Morphology of The Fungi Isolates Of Endophytic

\begin{tabular}{|c|c|c|c|c|}
\hline$\frac{\text { No. }}{1 .}$ & Organs Of Plants & Isolates & Characterization & Genus \\
\hline \multirow[t]{3}{*}{1.} & Leaf & ICED1 & $\begin{array}{l}\text { Colonies of the fungi colored dark green } \\
\text { (contains wheat), the margin of a colony of } \\
\text { white (contains wheat), the margin of colonies } \\
\text { shaped irregular. }\end{array}$ & Penicillium \\
\hline & & ICED2 & $\begin{array}{l}\text { Colonies of the fungi colored dark green } \\
\text { (contains wheat), the margin of a colony of } \\
\text { white (contains wheat) and is located only at the } \\
\text { margin, the margin of colonies shaped irregular. }\end{array}$ & Aspergilus 1 \\
\hline & & ICED3 & $\begin{array}{l}\text { Colonies of the fungi black (contains wheat), the } \\
\text { margin of a colony of white (contains wheat) } \\
\text { and located on the margin and close the colonies } \\
\text { are colored green, the margin of colonies shaped } \\
\text { irregular. }\end{array}$ & Aspergilus 2 \\
\hline 2. & Stem & ICEB 1 & $\begin{array}{l}\text { Colonies of fungi colored green (contains } \\
\text { wheat), the margin of a colony of white } \\
\text { (contains wheat), the margin of colonies shaped } \\
\text { irregular. }\end{array}$ & Penicillium \\
\hline & & ICEB2 & $\begin{array}{l}\text { Colonies of the fungi are white (contains } \\
\text { wheat), the margin of colonies shaped irregular. }\end{array}$ & Phialophora \\
\hline 3. & Root & ICEA1 & $\begin{array}{l}\text { Colonies of the fungi colored dark green } \\
\text { (contains wheat), the margin of a colony of } \\
\text { white (contains wheat), the margin of colonies } \\
\text { shaped irregular. }\end{array}$ & Penicillium \\
\hline
\end{tabular}




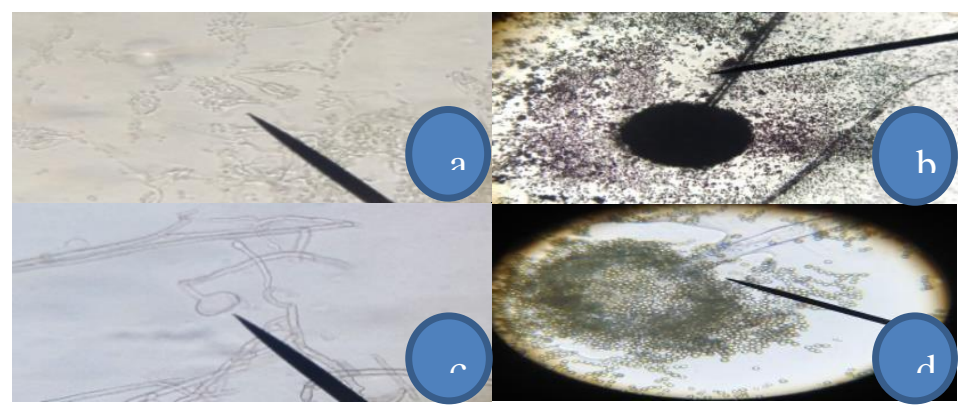

Figure 1. The anatomical structure of the fungi endophytic: a) Penicillium, b) Aspergillus 1, c) Phialopora, d) Aspergillus 2
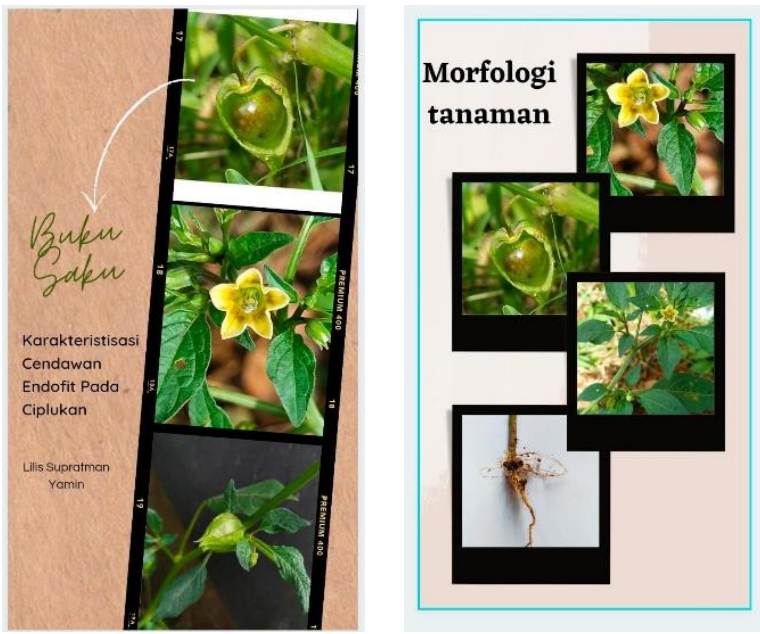

Figure 2. The Cover of the Book pocket

To determine the feasibility of the use of the pocket book as the teaching materials have through the test of validation by media experts and learning matter experts fungi. The results of the validation test can be specified as follows:

1. The results of the validation of media experts learning

\begin{tabular}{llc}
\hline No. & Aspects Assessed & Scores \\
\hline 1 & cover page & 84 \\
2 & preface & 86 \\
3 & the instructions for the use of pocket-book & 82 \\
4 & the stages of studying a book pocket & 83 \\
5 & how to learn pocket-book & 83 \\
6 & table of contents & 85 \\
7 & description of the morphology of the plants & 84 \\
8 & description of the anatomy of the fungi endophytic & 89 \\
9 & figure & 84 \\
10. & completeness of the contents of the pocket book & 82 \\
Total/average & $851 / 85.11$ \\
Commentary : 'valid' this means that pocket books can be used as a learning medium
\end{tabular}


2. The results of the validation of material experts fungi

\begin{tabular}{llc}
\hline No. & \multicolumn{1}{c}{ Aspects Assessed } & Scores \\
\hline 1 & cover page & 85 \\
2 & preface & 84 \\
3 & the instructions for the use of pocket-book & 82 \\
4 & the stages of studying a book pocket & 85 \\
5 & how to learn pocket-book & 83 \\
6 & table of contents & 82 \\
7 & description of the morphology of the plants & 86 \\
8 & description of the anatomy of the fungi endophytic & 84 \\
9 & figure & 82 \\
10. & completeness of the contents of the pocket book & 82 \\
Total/average & $835 / 83.50$ \\
Commentary : 'valid' this means that pocket books can be used as a learning medium
\end{tabular}

The results of the validation pocket book based on the quality of content, quality of language, the quality of the presentation, and the quality of graphics is in the category valid. Variety of fungi endophytic presented to motivate the students to dig more about the benefits and test the physiology advanced. The results of similar research can be seen in the research Mahardhika et al. (2021) stated that fungi endophytic on Ciplukan plants can inhibit the growth of pathogenic bacteria such as Escherichia coli and Staphylococcus aureus. Rostikawati and Lilis Supatman (2021) stated that the ability of fungi endophytic in inhibiting the growth of bacteria due to fungi endophytic produce the secondary metabolite compounds. Secondary metabolites are suspected to have the ability antimicrobial activity contained in the supernatant of the fermentation (filtrate extracellular) including saponins, flavonoids, terpenoids, alkaloids, tannins, and glycosides (Govindappa et al., 2011 and Smibert \& Krieg, 1981). Moat (2002) and Atlas (1997) stated that the indicator of the inhibition zone on the media is seen as evidence that the fungi endophyte is able to suppress the growth of pathogenic bacteria. This suggests that allegedly Ciplukan plants can be used as a herbal medicine in the treatment of diseases caused by Escherichia coli and Staphylococcus aureus. The structure morphology and anatomy of the fungi described by characterization. In terms of color, margin, texture to benefits for everyday life. In the book the pocket (figure 2), described that the fungi endophytic can be cultured and used through a series of test physiological and test the pathogenicity of a disease. Darwo (2008) and Christhensen (1969) stated that this could motivate the students to develop the ability of researching to fungi endophytic for the detection of disease or cosmetics even to increase food production.

\section{Conclusion}

Pocket books are a small size book to carry everywhere. Based on the results of the study, four types of endophytic mushrooms, namely two different Aspergilus, Penicillium, Phialophora, can be studied further. The results of the feasibility test by learning media experts and fungi material experts get the results of "valid" criteria and produce suggestions and comments "can be used as a source of learning". 


\section{References}

Anjelita, Ria, Syamswisna dan Eka Ariyati. (2018). Pembuatan buku saku sebagai media pembelajaran pada materi jamur kelas X SMA. Jurnal Pendidikan dan Pembelajaran khatuslistiwa.Vol.7no.7.

Asyhari. A dan Silvia H. (2016). Pengembangan media pembelajaran berupa buletin dalam bentuk buku saku untuk pembelajaran IPA terpadu. Jurnal ilmiah pendidikan fisika al-biruni, 5 (1), 1.

Atlas. R.M. (1997). Handbook of Microbiological Media. CRC Press.Inc Boca, Raton, Florida

Christensen M. (1969) Soil microfungi of dry to mesic conifer hardwood forests in Northern Wisconsin. Ecology 50: 9-26.

Darwo, Sugiarti. (2008). Beberapa jenis cendawan ektomikoriza di kawasan hutan sipirok, tongkoh, dan aek nauli, sumatera utara. Jurnal peneliltian hutan dan konservasi alam $5: 157-173$.

Ferdiani, R.D, Murniasih T.R. dan Suwanti V. (2017). Penggunaan media bola-bola statistik. Jurnal pemberdayaan masyarakat, 2 (2).

Govindappa M., Nagar S.S., Poojasri M.N., Sadananda T.S., and Chandrappa C.P. (2011). Antimicrobial, Antioxidant, and In Vitro Antiinflamatory Activity of Ethanol Extact and Active Phytochemical Screening of Wedelia trilobata (L). Journal of Pharmacognosy and Phytotherapy 3:(43-51). https://doi.org/10.5897/JPP.9000012

Mahardhika, Wahyu Aji, M.G. Isworo Rukmi dan Sri Pujiyanto. (2021). Isolasi kapang endofit dari tanaman ciplukan (Physalis angulaya L.) dan potensi antibakteri terhadap Escherichia coli dan Staphylococcus aureus. Niche Journal of Tropical Biology. Volume 4 (1) : 33-39. https://ejournal2.undip.ac/index.php/niche.

Mawardi Doni. (2009). Cara Mudah Menulis Buku dengan Metode 12 Pas. Jakarta, Indonesia : Raih Asa Sukses

Moat AG, Foster JW, Spector MP. (2002). Microbial Physiology. Edisi ke-4. Wiley-Liss.

Murniasih, T. R. dan Ferdiani R. D. (2018). Aksiologiya. Jurnal pengabdian kepada masyarakat pelatihan smart diagram venn pada materi himpunan SMP, 2 (2), 125 130.

Rostikawati, R. Teti dan Lilis Supratman. (2021). Uji antibakteri obat kumur ekstrak etanol tanaman ciplukan (Physalis angulata L.) Terhadap bakteri gram positif. Quagga. Vol. 13 Issue, nomor $1 .$.

Sankarto, Bambang S dan Endang S Setyorini. (2008). Pedoman Pengemasan Informasi. Materi Pendampingan Pusat Informasi Pertanian dan Unit Pelayanan Informasi Pertanian Kabupaten. Jakarta, Indonesia : Departemen Pertanian. 
Smibert. RM , N.R. Krieg. (1981). General characterization. di dalam manual of Methods for General Bacteriology. American Society for Microbiology. Washington DC.

Sukaesih, S, dan Alimah. (2012). Penerapan praktek pembelajaran bermakna berbasis better teaching learning (BTL) pada mata kuliah microteaching untuk mengembangkan professional calon guru. Jurnal penelitian pendidikan Unnes, 29 (2), 165-172.

Supratman, Lilis dan R. Teti Rostikawati. (2021). Comparison Analysis of Temperature Treatment on Cutleaf Groundcherry's Leaf and Stem. JBER. Volume 2, nomor 1. https://journal.unpak.ac.id.

Susilana, Rudi dan Cepi Riyana. (2008). Media Pembelajaran Hakekat Pengembangan Pemanfaatan dan Penilaian. Bandung, Indonesia : Wacana Prima. Pusat Bahasa. (2016). Kamus Besar Bahasa Indonesia Pusat Bahasa. Jakarta, Indonesia : Gramedia. 